\title{
Women on the Move: Mobility in Evelyn Conlon's Fiction
}

\author{
M. Teresa Caneda-Cabrera \\ University of Vigo, Spain \\ tcaneda@uvigo.es
}

Copyright (c) 2017 by Teresa Caneda-Cabrera. This text may be archived and redistributed both in electronic form and in hard copy, provided that the author and journal are properly cited and no fee is charged for access.

\begin{abstract}
This article explores the representation of women's mobility in Evelyn Conlon's fiction and focuses on texts in which the female protagonists are depicted as "women on the move" and coded as transgressors and trespassers. The article discusses Conlon's fiction of mobility in the light of patterns of displacement and dislocation which are recurrent in the novels and stories analyzed. Although the writer consistently disrupts unified patriarchal narratives of "at-homeness", the article argues that her works expose also the need for connection and continuity and, thus, embody a reformulation of more open forms of belonging and a proposal for more inclusive identity paradigms.
\end{abstract}

Key Words. Evelyn Conlon, Mobility, Irish Women, At-homeness, Identity, Irishness, Contemporary Irish Fiction, Subversive Writing

Resumen. Este artículo analiza la representación de la movilidad de las mujeres en la ficción de Evelyn Conlon y presta especial atención a aquellos textos en los que las protagonistas aparecen caracterizadas como mujeres en continuo movimiento y son retratadas como transgresoras. El artículo examina la movilidad en la ficción de la escritora irlandesa a la luz de las nociones de desplazamiento y dislocación recurrentes en las obras seleccionadas. A pesar de que Conlon fractura de modo consistente los relatos patriarcales sobre la identidad, el artículo mantiene que su ficción expone también la necesidad de conexión y continuidad constituyendo, por lo tanto, una reformulación de paradigmas identitarios más tolerantes y propuestas de pertenencia más inclusivas.

Palabras clave. Evelyn Conlon, movilidad, mujeres irlandesas, identidad, Irlanda, ficción contemporánea, escritura subversiva

In his introduction to Cultural Mobility: A Manifesto, Stephen Greenblatt contends that certain cultures engage routinely in celebratory performances of their authenticity and cultural legitimacy through rituals and discourses which are often identified with the notion of "athomeness" (2010: 3) and presented as "the necessary condition for a robust cultural identity" 
(3). Although Greenblatt does not refer specifically to Irish culture, some of his arguments seem to fit appropriately the case of Ireland where tourism, for example, certainly depends on what he calls "a commodification of rootedness" (5), a process that is described in the following terms: "cultures that appear to have strikingly unmixed and local forms of behavior become the objects of pilgrimage and are themselves fungible as mobile signifiers" (5). Likewise, what the critic identifies as the dialectic of "persistence and change" (2) underlying the formation of many cultural identities aptly echoes recent approaches to issues of mobility and stasis in Irish Studies. While Greenblatt claims that accurate cultural analyses must bear in mind various forms of mobility such as exile, emigration and wandering, he also perceptively observes the need to account for "the persistence, over very long time periods and in the face of radical disruption, of cultural identities for which substantial numbers of people are willing to make extreme sacrifices, including life itself' (2).

In the pages that follow I shall draw on Greenblatt's dialectic of persistence and change, which I believe may be invoked to dislodge other kinds of binary notions underlying conventional thinking about identity and mobility, in order to explore the contradictions inherently attached to those notions specifically in the Irish context where the experience of uprootedness and homelessness coexist with discourses of authenticity, wholeness and legitimacy. Paradoxically, although mobility has been a vital part of Irish culture and identity, strongly characterized by the experiences of emigration, exile and diaspora, the institutionalization of Irish nationalism and the emergence of the Irish Free State were accompanied by rigid constructions of gender which confined women to the domestic space and limited their roles to static identity positions. As I will argue in my discussion of the representation of women's mobility in Evelyn Conlon's fiction, Conlon has consistently responded to the essentialist rigidity of the categories "Irish" and "woman" by registering stories in which the female protagonists are depicted as "women on the move" and are often coded as transgressors and trespassers. In particular, attention will be given to Conlon's disruption of unified narratives of "at-homeness" in her fiction, where women with multiple affiliations and multi-located identifications constantly travel across different kinds of borders as they struggle forcefully to direct the movements of their own lives.

Doubtless, the notion of a fixed relationship between a particular culture and a stable territory, extremely powerful in nationalist thinking, has been exceptionally relevant in traditional conceptualizations of Irish womanhood, as feminist scholarship has denounced. Sabina Sharkey, for example, comments on the complex intersection of gender and national identity positionings in Ireland and she aptly remarks that:

Where the body of the territory, and the body of the colonial site, was gendered female, the counter hegemony of nineteenth-century Irish nationalists fashioned the male hero as one who liberated the abducted female through repossession. Male identity positions altered in simple and superficially effective ways, the colonial male was now represented as the abuser and the native endeavour deemed chivalric. However, the identity positions allocated to the female remained static and women were still marginalized. (2008: 127)

Moreover, the critic appropriately refers to the crucial political and social agencies of Irish women in the first decades of the twentieth century, when together with the socialist, labour and Republican movements, the women's movement contributed to the destabilization of British rule. The hegemony of the Church and Eamon de Valera's 1937 Constitution promoted a free state that would be clearly Catholic and where the nationalist cultural production of the period heavily relied on the feminization of Ireland. As Sharkey contends, on the one hand this "feminized muse" (127) functioned to inspire male agency and, on the other hand, "women's 
historical agency would not be admitted in the public sphere"(127). Ultimately, the symbolic association of (female) body and (national) territory channeled a sociopolitical discourse which portrayed women as passive (immobilized) objects: "the previously violated body of Ireland was now conflated with that of Irish 'womanhood', and the desire to recuperate, to regain lost ground, was attempted through the assertion of strict controls over women's positioning within the state" (Sharkey 2008: 127).

Article 41 of de Valera's constitution pledging that "the state shall endeavour to ensure that mothers shall not be obliged by economic necessity to engage in labour to the neglect of their duties in the home" (quoted in Sharkey 128) discriminated against women who went out to work. Given the central role attached to marriage and family, the position of women in the paid labour force was regarded as "abject or marginal" (Sharkey 2008:128) and, because of the public service ban on married women, many female public servants had to resign. Whereas in Europe and the US the Second World War introduced unprecedented changes which affected dramatically the social, economic and geographical mobility of women (McEuen 2016), in Ireland these institutionalized forms of "immobility" and inequality deprived women from moving beyond the socio-economic spaces into which they were born.

In the past twenty years, the reformulations of the notion of Irish identity that emerged in "post-nationalist"1 Ireland have often had to negotiate many of these problematic legacies, associations and iconographies which had traditionally marginalized women, through the development of new enabling discourses and tropes now expressing inclusiveness and symbolizing Ireland's modern diversity. Significantly, in her 1990 inaugural speech, former President Mary Robinson, unquestionably one of the most outstanding public figures of contemporary Ireland, promoted a more inclusive understanding of politics, tradition, religion and gender, through the adoption of the "cherishing diaspora" motif. As has been remarked, the theme of the Irish diaspora was, thus, embedded in feminized yet subversive language since "the choice of the word 'cherish' emphasised a positive notion of nurture rather than the selfsacrificing duty of 'caring' associated with a Catholic version of 'Mother Ireland"' (Walter 2001: 12).

In her address to both Houses of the Oireachtas in 1992 President Robinson invoked once more the Irish diaspora:

I had in mind all our exiles, all our emigrants - past and present - when I put the light in the window of Aras an Uachtarain. I was not prepared for the power and meaning which a modest emblem would have. But we have reason to know in Ireland how powerful symbols are: that they carry the force of what they symbolise ... that light reminds us - that the community of Irish interest and talent and memory extends far beyond our boundaries, far beyond Europe's boundaries . . . (qtd. in Walter 12)

Here Robinson seems to speak for a dialectic of persistence and change since her redefinition of the Irish diaspora simultaneously encompasses the concepts of diversity and mobility together with those of continuity and tradition. More importantly, her undermining of the rigid boundaries through which Irish identity has traditionally been defined is further complicated by the domestic symbols evoked, all charged with gendered signification. As has been noted, the lighted candle in the window of Aras an Uachtarain is marked with double implications, both as a symbol for the official presidential home and the "domestic "home"" where the President and her family live, and also "a permanent reminder to those who had 'stayed put' in Ireland of the absent members of their "imagined community" (Walter 2001: 12).

Although the exploration of the concept of diaspora ${ }^{2}$ in the Irish context is beyond the scope of this article, my invocation of Robinson's addresses and, particularly, her personal 
redefinition of the concept of diaspora through imagery and language charged with renewed gender-linked associations, is meant to reflect on the potential of her own elaborations on the motifs of identity and mobility for my own discussion. The common understanding of Irishness, traditionally bound up with notions of purity, enclosure, coherence and settledness is questioned through Robinson's invocation of a new space of intersections and interrelations, "past and present", now defined by external influences and movements: "beyond our boundaries, far beyond Europe's boundaries". Moreover, whereas the Irish woman has been typically defined through her familial connections and her attachment to the domestic realm, in her role as the first female president of Ireland, Robinson herself embodies alternative possibilities for other more active and mobile forms of identity with vital resonances for women. Ultimately, as Anne Fogarty has appropriately remarked in relation to her emblematic inauguration speech:

The conjunction of female poetic and political pronouncement seemed entirely fitting on this occasion which many viewed as a crowning moment in the history of Irish women's protracted struggle to attain equality, justice, and, above all, ownership of those male-dominated public discourses that had silenced and represented them for so long. (Fogarty 1999: 256)

This conjunction of poetics and politics has been a dominant feature in the work of the Irish novelist and short story writer Evelyn Conlon, who has herself acknowledged the inextricable connection between her writing and her political consciousness: "I don't think you can be a 'feminist' writer, I think you're a writer. I am a writer who is a feminist. And, my feminist consciousness affects the sort of things I enjoy writing about" (Moloney 2003: 29). As has been noted, by creating fissures in traditional notions of gender roles and identity claims, Conlon's fiction contributed to a revolt which affected a wide-reaching and radical change in conditions, lifestyles, beliefs and attitudes for women in Ireland. Her early writing represented in the context of women's fiction the corresponding change in mentality which the feminist movement, in which she participated actively, ${ }^{3}$ was advocating at the time in the sociopolitical sphere.

In the Field Day Anthology of Irish Writing the scholar Clair Wills interestingly introduces the work of Conlon in connection with the tradition of "subversive writing" represented by authors like Edna O'Brien. The critic observes that female writers have long been exploring the situation of Irish women, "challenging customs and prejudice, and telling subversive truths" (Wills 2002: 1125) and it is precisely in this context where Conlon is presented as a sort of radical inheritor of O'Brien:

... more explicitly feminist writers such as Evelyn Conlon, made their own contributions to the social turbulence, exploring the tensions between traditional values and the demand for personal and individual freedom. (1125)

From her early fiction as a woman writer creating fissures which de-stabilized traditional discourses about gender roles and Irishness, with novels like Stars in the Daytime (1989) to the most recent Not the Same Sky (2013), in which she problematizes history and memory, Conlon has continued to revise the tensions between traditional values and women's demand for individual freedom, as she denounces the rigidities of patriarchal discourses and institutions from which women have been excluded. Stars in the Daytime, the first novel by an Irish woman writer to be published by Women's Press, has been discussed as representative of the fiction from the 1980s onwards "where the impact of women writing is marked in narrative modes geared to the representation of an abused subjectivity" (Patten 2006: 267), and typically the 
genre of the novel became "a means by which by which marginalized female voices claimed authority in response to the ingrained misogyny of Irish life" (Patten 2006: 268).

Through the story of the protagonist of Stars in the Daytime, Rose, a young woman who becomes pregnant after an encounter with a stranger on a train and closes herself away in a room where her only communication with the world is a half door, Conlon explores notions of exclusion and inclusion, belonging and unbelonging to the Irish nation. Significantly, as Heather Ingman has observed in her analysis of the protagonist:

Rose is determined to live her life in a different way from her mother and grandmother ... in an effort at self-education she takes on various menial jobs, experiments with sex, marries briefly, has a miscarriage and goes travelling in an effort to free herself from the last lingering constraints of her upbringing. Yet even abroad she does not entirely break the dialogue with her nation. (2007: 50)

As Ingman suggests, in her role as a single mother living in Ireland, Rose shows her resistance to the essentialist rigidity of the categories "Irish" and "woman" and disrupts the unified narratives of a "home" whose rules are "those of a sneaky bunch of men who had always been old" (Conlon 1989: 130). Ultimately, by registering a story in which the female protagonist becomes a transgressor who must cross different kinds of borders (physical, cultural, social, religious and political) in order to direct the movements of her own life, Conlon tests the limits of personal and social mobility for Irish women at the time. Likewise, through the narrative of a woman character who must negotiate her attachments to family and nation, the writer explores the complexities of the dialectic of persistence and change underlying the notion of Irishness in the specific case of women. For Rose the experience of being outside, "where she had always been most comfortable" (Conlon 1989: 166), coexists with her legitimate desire to belong as she hopes to discover "some sort of woman's truth that could be stitched together with what was already there to make a whole truth" (171). It is thus how, from her marginal position as an outsider, ${ }^{4}$ Conlon's character pushes the boundaries of Irishness beyond traditional definitions as she struggles "to open her nation up to other voices, most notably here that of the single mother" (Ingman 2007: 51)

If in her first novel the experience of travelling may well be seen more as an inner process of journeying, from an initial stage of strangeness to a final moment of self-awareness, than as a series of physical displacements structuring the plot, the actual practice of travelling remains, nevertheless, a prominent and recurrent theme in Conlon's later fiction. As Caitriona Moloney explains: "Conlon's fiction addresses the complications imposed on identity by movement: the traditional exile and escape paradigm, as well as relatively new variables in the migration story, asylum-seeking refugees and returning Irish emigrants" (2003: 17). In her short preface to her interview with Conlon, Moloney highlights the relevance of the story "The Park" (Conlon 2000a), from the collection Taking Scarlet as a Real Colour (1993), ${ }^{5}$ where "Immigration is juxtaposed with the ultimate confinement, prison" (Moloney 2003:18).

In "The Park" Conlon revisits the well known joycean motif of escape from Ireland's paralysis. ${ }^{6}$ Using her typically humorous tone, the writer explicitly introduces emigration as the only possible escape from the repression of a society strictly delineated according to Irish Catholic values. Significantly framed by the event of the Pope's visit to Ireland in 1979, the story deals with a group of young people who, "concerned at the assumption that we all wanted the pope here" believe that "something should be done about it" (Conlon 2000a: 34-35) and, thus, decide to paint slogans to show that "there was some opposition in the country"(35). The narrative focuses on the many movements of Brigid and her friends as she first drives from Maynooth to Dublin where they will paint the slogans, then through north County Dublin townlands along "roads that skirted the pope's intended route to Drogheda" (41) and finally to 
the park to paint a "harmless slogan" (43) on the monument built for the Pope. After seeing off a friend who was emigrating and, admittedly, as a reaction to the airport and "the sense of people fleeing" (43), Brigid decides to go out painting with her friend Sheena once more. Unlike Sheena, who announces that she is also leaving the country, Brigid stays in Ireland where she is caught and sentenced to six months in prison.

At a time when those who do not emigrate are confined for protesting the constraints of a punitive society, Brigid's dreams of flight seem to be the only available escape: "Brigid dreamt that she was a bird flying into people's kitchens, into canteens, on to building sites. Switiching the bloody radios off as they built up cosy pictures of the wonderful preparations for the wonderful man" (35). Ultimately, by featuring a female protagonist who experiences an imposed estrangement from her society due to a conflicting relationship with her homeland, the story seems to be making a statement about the experience of what the critic Roberta Gefter Wondrich has described as "exile from within, the inner exile of those who stay at home but are equally alien and estranged from their own country and context of provenance" (2000: 2 ).

As Gefter Wondrich argues, the notion of "emigration and leave-taking ... still predicate an ambivalent, uneasy response to the individual construction and appropriation of an original homeland" (2000: 2). Although the critic does not address specifically the issue of gender in her examination of travelling (mainly exile) in recent Irish fiction, some of her considerations seem most appropriate for a study of the intriguing and pervasive patterns of mobility in Conlon's novels and stories. Characterized as restless subjects always on the move and portrayed through experiences such as transatlantic journeys and transcontinental migration, Conlon's female characters vary from solitary wanderers to passengers on ships and planes. Marked by departures and arrivals, they often exist in transit and are depicted through incidents that problematize "at-homeness", otherness and in-betweenness. ${ }^{7}$ More often than not, the varied experiences of travel represented in Conlon's stories involve the negotiation of differently located selves through relationships to new places and encounters with others.

"Two Good Times", a short story which Conlon herself has described as "not about immigration specifically but about the longing to be in other places" (Conlon 2012), opens with a scene in which a couple, Constance and Gregory, are having dinner. We learn from their conversation that they had been to Australia some months before. Through a sort of unobtrusive flashback we follow them on the airplane as they fly over India, Bangkok, and Malaysia and we enter their mind as they experience the joy of being in a new place, Sydney. When they go back to Ireland, Constance realizes that "something happened" and "she found difficult for her to be grateful for the good things of her life, she missed the plants, the peculiar animals ... she longed for the infinite distance ... she seemed sad as if she had lost something of the future" (Conlon 2000b: 116). The end takes the reader back to the opening scene with Constance negotiating her new sense of identity, in relation to Gregory and herself, as she deals with the challenging effects of her recent experience of displacement through her journey of discovery and transformation. At stake here is Conlon's concern with the unsolved paradoxes of mobility as an experience which may be both distressing and liberating. In elliptical and playful ways, the text deals with the idea that "people who might have been constrained by the restricted thought and practices of traditional communities discover exhilarating new forms of freedom, but may also become fretful and unsure about the main relationships in their lives" (Kiberd 2016: $x$ ).

In "Two Good Times" as in Skin of Dreams (2003), the reader is left with the impression that for each of the two women protagonists, their journeys to Australia and the US respectively, have challenged home certainties and triggered off the appearance of competing attractions half way between the old and the new, between persistence and change. Skin of Dreams opens with Maud (named after Maud Gone), seat-belted on an Aer Lingus plane on her way to New York, shortly before landing, concerned with getting through customs, and ends with her return to 
familiar Dublin where, ironically, after all the changes she has experienced "the Custom men didn't even notice Maud as she walks past them" (Conlon 2003: 230). The plot focuses on the story of Maud's search for the truth as she discovers that her grand-uncle was hanged in the 1940s for a murder he did not commit and, obsessed by this event of her family's past, she is drawn to America where she joins other "journeyers", like her, "family members of murder victims who do not agree with capital punishment" (122). Upon her arrival in the US she signs up for a peculiar pilgrimage:

[S]he trouped to schools, churches, lecture theatres, parks, concerts, demonstrations. She got in and out of cars and vans, had tea with priests and pastors, listened with both ears open when required, closed one or half closed both when the exhaustion of constant moving and listening and thinking made people's conversation hollow and tired. (157)

Although moving away from the familiar has been painful and disorienting for Maud, she has also managed to gain enlightenment and revelation. Thus, the novel ends with her returning home a different person, as a woman who "had at least hit back at her history" (231). In this respect, Skin of Dreams exposes both the disruptive and constructive aspects of travelling, "of strangement or dislocation, of a voluntary, 'being elsewhere', away from Ireland, ... the idea of deplacing oneself from one place and country to another in order to pursue a path of advancement and self-discovery which ultimately moves to return" (Gefter Wondrich 2000: 8).

The notion of "being elsewhere" in order to rediscover both home and oneself away from home becomes essential in Conlon's fiction in which, as I have suggested, women are often in transit and inhabit liminal spaces between departure and arrival, between before and after. In her recent "Disturbing Words", a story about borders and borderlands, published in the collection The Glass Shore: Short Stories by Women Writers from The North of Ireland (2016), Conlon reflects, once more, on the politics of mobility as she typically deals with a narrative of identity conflicts in which movement, belonging, personal and public histories are cunningly intertwined. The first person narrator, a woman living in Abu Dhabi, returns "home" in a border town in the North of Ireland for her parents' funeral where she mourns the loss of her mother, who had asked her to "always live away from the border" (Conlon 2016: 266) and her father who, we learn, "had been hurt young by the border; the line ran on the top of their ditch" (263).

Significantly, at the wake, the protagonist's present thoughts blend with the memories of her own grandmother who had herself mourned the loss of friends from both sides of the border. The grandmother's disturbing words from the past as she once wondered about origins, place and politics are, thus, evoked by the character at the present moment: "So, if you were born in the six counties before now, where will they say you were from? You can't have been from somewhere that never was" (263). Immediately after the funeral the narrator realizes that the tree her parents had grown "to make sure that its roots, and now its branches, would spread across the line" (368) is to be cut down and she instinctively climbs up to the top and perches there waiting for the workers to withdraw the blades. The story ends with the protagonist explaining that she needed to be in a place "where I'm not known as the person who went up the tree that went over the border" (269) and closes with an epilogue in which she is back in "the desert" talking about border crossing, ironically enough, at a party. In this case Conlon chooses to explore the intricacies of "at-homeness" in a complex geopolitical scenario, where the sense of attachment and belonging to a particular homeland has been painfully shaped by a traumatic process of discontinuity.

Typically, transit places such as borders, inspection offices, railway stations, airplanes, airports, customs, ships' decks and hotels feature prominently in Conlon's work; concurrently, so do letters. In her epistolary novel A Glassful of Letters (1998) the plot is disclosed through 
the juxtaposition of the correspondence between several characters, including a political prisoner, an architect who has recently migrated to New York and Helena, an Aer-Lingus flight attendant with multiple affiliations, as a career woman and a mother, and with multi-located identifications far beyond Dublin. Helena's choice of job has been determined by her relentless urge to resist the strictures of a fixed role and identity: "I thought that I had the brains to carve out for myself a small piece of fresh air that would keep me sane, and the most important component of that fresh air was movement" (Conlon 1998: 3). In a novel that develops mainly through the movement of letters and exposes both the longing for stability and the pursuit of change, the character of Helena paradigmatically embodies the notion of a mobile form of Irishness. She is constantly in and out the country, and her identity, shaped by discontinuity and displacement, is conveyed by her need to be both home and away, separate from but connected to her homeland: "I could not live without my job (not any old job, the one that takes me on and off this island, in and out of my street) so that the out-ness and in-ness mean something when I have them" (3).

Whereas most of Conlon's fiction to date has been characterized by a continuous exploration of how the ordinary lives of ordinary women are affected by the pervasive predominance of patriarchal mythologies and discourses, more recently the writer has turned to history and has dealt with the recovery of female voices which had remained silenced in malecentred versions of the past. This is the case of "Dear You" (2013) a short story based on the life and deeds of Violet Gibson, the Irishwoman who shot Benito Mussolini on April 7, 1926. To save himself from the embarrassment of having to expose publicly the fact that he had almost been killed by a woman, Mussolini managed to keep the attempt on his life out of the media and Gibson, initially sent to jail for a year and later declared insane, was finally confined to a mental institution in Northampton for the rest of her life.

Conlon followed Gibson's journey through Italy and England and learned that the letters she wrote explaining her reasons to shoot Mussolini were never posted. Admittedly, Conlon's short-story is meant to be an act of restitution which aims to bring back Gibson's version of the facts through her perspective and, more importantly, through her own voice. ${ }^{8}$ The letter Gibson writes, the story we read, is literally a text in transit. Kept as a message in a bottle addressed to a "you", the letter will travel until it arrives somewhere where it will be read:

I could have said more, perhaps explained more, it may appear to you that I have just given tufts of details, but I hope that it suffices to bring your attention to me and to the others, to let you know that my thoughts and feelings have remained mostly intact, despite the door having been slammed, despite all that was dear to me having been stolen from me, despite the fact that the only way I can speak to you is through this perhaps unreliable bottle. Signed, Violet Gibson. (Conlon 2013a: 66)

In this respect, Conlon's writing calls attention to itself as a form of motion and relocation, as it embodies a journey to the historical past in order to liberate a woman's story from silence and confinement. As has been remarked:

It is not by chance that Conlon chose to first publish the story in Italy at the same time as its Italian translation, each English page facing its Italian version. In such a way Violet Gibson re-enters Italian culture and historiography, as well as individual readers' imaginations and emotions, through translated literature. (Bollettieri Bosinelli and Torresi 2016: 6) 2013a: 66) 
Significantly, the reference to letters as containers of buried stories, secrets kept for a long time, dead revelations awaiting to be brought to life, conform to a recurrent motif in Conlon's narratives of mobility. As I have argued in relation to "Dear You", by her imaginative recovery of Gibson's letter Conlon transforms a story of invisibility, exclusion and repression into a challenging and self-affirming counter-narrative. It is thus how her writing becomes itself a form of motion and migration or rather a transmigration, a movement from one place to another, in which a disenfranchised discourse and a silenced story are not only reappropriated and foregrounded but made to occupy a hegemonic position. ${ }^{9}$

This becomes obvious in her latest novel, Not the Same Sky (2013), fundamentally a book about women, journeys and letters in which Conlon further complicates her already complex portraits of female mobility by introducing also her concern with history and memory. Not the Same Sky stands as the ultimate example of writing as transmigration, with the dead being invoked through an act of memory on the writer's part and the text itself functioning as a memory site. As Conlon explains in the acknowledgements: "This novel, which started with a personal 'hungry grass' moment in Gundagai in 1973, is based on the true story of the Irish Famine Orphan Girls, who were shipped to Australia between 1848 and 1850" (Conlon 2013b: 254).

Most of the narrative concerns the voyage of a group of girls who left England on October 28, 1849, on the Thomas Arbuthnot under the care of Surgeon Superintendent Charles Strutt and is structured through thirty-five chapters with a diary-like style which appropriately fits the journey theme of the novel. Through her typically clear-sighted observations, Conlon focuses on the characters of Honora, Julia, Bridget and Anne and provides a rigorously detailed and deeply humanized account of their voyage and of their subsequent arrival in Australia. Symbolically, Conlon's own task as the writer of a novel attempting to recover the forgotten voices and the untold stories of the orphan girls is echoed in the task of the character of Joy Kennedy, the Irish sculptor of headstones, a woman "always wanting to be someplace else" (Conlon 2013b: 1), who is commissioned to carve a memorial to the Irish orphan girls in Sydney.

In Not the Same Sky the experience of being in transit and existing between places strongly echoes other stories and novels by Conlon. The exploration of identity issues in relation to the notions of movement and belonging which I have been discussing up to this point becomes essential in this particular novel. Readers will recognize here variations of the mobility patterns of previous fiction where women on the move also get on and off planes, read maps, sleep at hotels, think about foreign lands and rediscover themselves mainly through experiences of "puzzlement", "strangeness" (Conlon 2013b: 248) and displacement in plots largely framed between departures and arrivals. ${ }^{10}$ However, as I will discuss, in Conlon's latest novel the theme of displacement acquires a significantly different dimension.

The book opens in Dublin in 2008 with Joy first receiving a letter from the friends of the Memorial Committee in Australia explaining that "it might be both interesting and appropriate to have a mason from Ireland" (2) and closes with her back home, after her journey, feeling that "She was going to have to live with those girls, they were inside her now" (249). As has been remarked in a recent review:

The use of the Prologue and final chapter to 'book-end' the body of the novel, provide a further structural emphasis on the novel's themes of memory, memorialising and naming. But these are also closely linked in the novel to the concept of the journey- actual, physical journeys and those that take place inside the mind, as well as the relationship between them. (Pelan 2013: 191) 
In the broader context of colonial mobility, with forced emigration and human trafficking looming in the background of the novel, the Famine orphan girls' journey becomes in itself a border that splits their lives into that which existed before and that which existed after. In striking contrast with the sea voyage undertaken by the Irish girls sent by the British Government to Australia as a source of cheap domestic labour, Joy's modern transcontinental journey is tailored to fit her tourist demands with a stopover in Bangkok and Singapore. When she visits the Hyde Park Barracks Museum, where together with the convicts the girls would have had to stand "like exhibits at a fair while prospective employers looked upon them" (Conlon 2013b: 238), and sees a sign that proclaims that "many of these women were refugees of the Great Irish Famine", Joy thinks to herself: "No, they weren't. That suggests that they were taking refuge, shelter. They were virtual prisoners, girl slaves" (237). Over the years "she had become good at picking up the unsaid, and perhaps the unknown" (207) and yet, as she explores this episode of the Irish past, she painfully struggles with the idea of the memorial she must produce and wonders about the meaning of it for the present: "I don't know what memorials are for now. Why pick one thing and not another" (249).

In her Women and the Irish Diaspora, Breda Gray refers to the relevance of commemoration as "an important site for the staging of continuity at a time of rapid social change in Ireland" (Gray 2013: 33). Within her broader reflection on the diaspora as a trope for Irishness, Gray's perceptive discussion of how the commemoration of the Famine may bear different implications, both as a tribute to fixity and mobility, continuity and change, aptly conveys Conlon's concern with the themes of memory, memorializing and journeys in Not the Same Sky. In contrast with the essentialized narratives that certain forms of memorialization seek to reinforce, ${ }^{11}$ Not the Same Sky raises questions about the practice of commemoration: "It depends on what memorials are for. Are they to let us know? To make us accept? Or are they to make us weep?" (Conlon 2013: 240).

Interestingly, the novel closes by suggesting a dialectic of persistence and change as, we are reminded, acts of remembrance are significant in as much as they are made relevant for the present: "In time Joy talked of these things less. She wanted to be where she was, the modern world, and she wanted to stay there ... but she was glad she had gone" (250). Ironically, Conlon's task as a writer grappling with how to tell the harsh experiences endured by the young Irish women forced to emigrate without the possibility of ever returning home, is echoed in the task of the stonemason who leaves for Australia feeling that "She had become connected to the girls in history" (249) and returns to Ireland with the realization that "She was going to have to live with these girls, they were inside her now" (249).

As I discussed at the beginning of this article, fixed concepts of gender subsumed within institutionalized constructs of the Irish nation have traditionally either excluded women from public spaces and discourses or rendered them as static. By contrast, Conlon's fiction of mobility, defined by displacement and dislocation but also by connection and continuity, represents a reformulation of Irish identity which disrupts unified narratives of belonging and proposes new paradigms of inclusiveness. As demonstrated in the texts I have analyzed, positioned as strangers and exiles within the public life of the nation, ${ }^{12}$ the Irish women (on the move) of Conlon's fiction - Rose in Stars in the Daytime, Brigid in "The Park", Constance in "Two Good Times", Maud in Skin of Dreams, the protagonist of "Disturbing Words", Helena in A Glassful of Letters - feel compelled to go beyond Ireland's boundaries and travel across borders, both metaphorically and literally. Yet, as I have argued, the female protagonists of her novels and stories paradoxically exist between their need to be home and away, separated from but also connected to their homeland. As Joy claims at the end of Not the Same Sky through the simile of migrating birds: "[b]irds go where the food is, a lot like us ... They get their accents and put them in their mouths, so no matter where they are we should know from where they came" (Conlon 2013b: 251). Ultimately, Conlon's stories of women on the move clearly 
denounce the rigidities of patriarchal definitions of "at-homeness" but, more importantly, they significantly engage in the creation of alternative possibilities for other more inclusive and mobile forms of Irishness.

\section{Notes}

${ }^{1}$ This article is part of the research project "Ex-sistere: Women's Mobility in Contemporary Galician and Irish Literatures", funded by the Spanish Ministerio de Economía y Competitividad (FFI 2012-35872). I would like to thank the coordinator Dr. Manuela Palacios González for her constant encouragement and her unflagging support. I am invoking here Richard Kearney's critical rethinking of nationalist political and cultural identity in his famous Postnationalist Ireland (1997). See also Eve Patten's “Contemporary Irish Fiction" (2006). The author refers to the literature of the contemporary period as "post-national" and explains that "writers simultaneously began to exercise a 'robust skepticism about the pieties of Irish nationalism' and geared their writings towards the subversion of official and causal narratives of the modern nation's evolution" (259-260).

2 The multifarious nature of the concept of diaspora has been the subject of a fruitful debate. See James Clifford (1994), Avtar Brah (1996) and Robin Cohen (1997). Specifically in the Irish context, Walter (2001) has argued for a more open definition of diaspora which expects "the two forms of consciousness [home/ away] to be held at the same time" (9).

${ }^{3}$ For an in-depth study of Irish feminist activism and the work of Irish feminist cultural projects in the 1970s and 1980s, see O'Toole (2005). For a discussion of Conlon's short fiction through the lens of the writer's feminist activism see Barros-del Río (2016) and Terrazas Gallego (2013).

4 Ingman invokes the work of Julia Kristeva as she contends that Kristeva's notion of women positioned as strangers and exiles within the public life of the nation is particularly well suited to Ireland in the twentieth century where "for much of the century, Irish women have been in a double bind, supporting their nation yet wishing for a greater voice in it" (Ingman 2007: 7).

5 "The Park" was first published in the collection Taking Scarlet as a Real Colour (1993) and later included in Telling: New and Selected Stories (2000) from where I will be quoting.

${ }^{6}$ For a discussion of Joyce's "Eveline" as a story of frustrated mobility in the context of patterns of escape and paralysis in Dubliners see Carregal and Caneda (2013/2014).

${ }^{7}$ Conlon herself has travelled several times to America and Australia where she has spent considerable time and has often commented on her interest in the Irish diaspora. In a recent publication on photographs of Irish migrating women which includes pieces by several other Irish female writers, Conlon explains : "I come from a long line of emigrators". See Palacios (2016: 162).

${ }^{8}$ For more information on the genesis of the story, see http://tv.uvigo.es/es/video/mm/15942.html

${ }^{9} \mathrm{I}$ am invoking here the concept of "transmigration" as has been used in Translation Studies, i.e., as a trope for the relocation of pre-existing texts within a new context. See Cutter (2005).

${ }^{10}$ For the sociologist John Urry (2007), who has written extensively about the spaces of modern life as "nonplaces", airports are "places of dwelling mobility" (148).

11 For a discussion of the paradoxical intersections between cultural remembrance, migration, and identity formation, see the introduction to the special issue of Atlantic Studies on "Irish Global Migration and Memory: Transnational Perspectives of Ireland's Famine Exodus" by Corporaal and King (2014). For an exploration of the competing concerns underlying the practice of public Famine memorials by stonemasons and visual artists, see specifically the article by Mark-FitzGerald (2014) in the same issue.

${ }^{12}$ See note 4.

\section{Works Cited}

Barros-del Río, María Amor. 2016. "Power, Gender and the Nation: Negotiations of Belonging in Evelyn Conlon's Short Story 'Park-Going Days"'. Estudios Irlandeses, 11. 12-22.

Brah, Avtar. 1996. Cartographies of Diaspora: Contesting Identities. London and New York: Routledge.

Bollettieri Bosinelli, Rosa Maria and Ira Torresi. 2016. "Message(s) in a Bottle: Translating Memory, the Memory of Translation". inTRAlinea, 18 http://www.intralinea.org/archive/article/2213 [retrieved 25/10/2016] 
Carregal Romero and M. Teresa Caneda-Cabrera. 2013/2014. "Female Mobility in James Joyce's 'Eveline' and Colm Toíbín's Brooklyn”. Papers on Joyce, 19/20. 55-74.

Clifford, James. 1994. "Diasporas”. Cultural Anthropology, 9.3. 302-338.

Cohen, Robin. 1997. Global Diasporas: An Introduction. London and New York: Routledge.

Conlon, Evelyn. 1989. Stars in the Daytime. Dublin: Attic Press. 1998. A Glassful of Letters. Belfast: The Blackstaff Press. 2000a. "The Park". Telling: New and Selected Stories. Belfast: The Blackstaff Press. 31-44.

2000b. "Two Good Times". Telling: New and Selected Stories. Belfast: The Blackstaff Press. 112-117.

- 2003. Skin of Dreams. Dingle: Brandon Press.

2012. A Conversation with the Author. University of Vigo, 29 November. http://tv.uvigo.es/es/video/mm/15942.html

—. 2013a. "Dear You / Caro, Cara". Ira Torresi (trans.). Tratti, 93. 42-67.

- 2013b. Not the Same Sky. Adelaide: Wakefield Press.

- 2016. "Disturbing Words". The Glass Shore: Short Stories from Women from Northern Ireland. Ed. Sineád Gleeson. Stillorgan: New Island. 261-269.

Corporaal, Marguérite and Jason King. 2014. "Irish Global Migration and Memory: Transnational Perspectives of Ireland's Famine Exodus”. Atlantic Studies, 11.3. 301320.

Cutter, Martha J. 2005. "Translation as Transmigration". Lost and Found in Translation: Contemporary Ethnic American Writing and the Politics of Language Diversity. Chapel Hill: University of North Carolina Press. 1-30.

Fogarty, Anne. 1999. “"The Influence of Absences': Eavan Boland and the Silenced History of Women's Poetry". Colby Quarterly, 35.4. 256-274.

Gefter Wondrich, Roberta. 2000. "Exilic Returns: Self and History Outside Ireland in Recent Irish Fiction”. Irish University Review, 30.1. 1-16.

Gray, Breda. 2004. Women and the Irish Diaspora. London and New York: Routledge.

Greenblatt, Stephen. 2010. "Cultural Mobility: An Introduction". Cultural Mobility: A Manifesto. Ed. Stephen Greenblatt et al. Cambridge: Cambridge UP. 1-23.

Ingman, Heather. 2007. Twentieth-Century Fiction by Irish Women: Nation and Gender. Aldershot: Ashgate.

Kiberd, Declan. 2016. "Foreword". Ex-Sistere. Women's Mobility in Contemporary Irish, Galician and Welsh Literatures. Ed. María Jesús Lorenzo-Modia. Newcastle: Cambridge Scholars. ix-x.

Kearney, Richard. 1997. Postnationalist Ireland: Politics, Culture, Philosophy. London and New York: Routledge.

Mark-FitzGerald, Emily. 2014. "Famine Memory and the Gathering of Stones: Genealogies of Belonging”. Atlantic Studies, 11.3. 419-435.

McEuen, Melissa. 2016. "Women, Gender and World War II". Oxford Research Encyclopedia of American History. http://americanhistory.oxfordre.com/ [retrieved 24/09/2016] 
Moloney, Caitriona. 2003. "Local Irish Identities: Evelyn Conlon”. Irish Women Writers Speak Out: Voices From the Field. Eds. Caitriona Moloney and Helen Thompson. Syracuse: Syracuse UP.

O'Toole, Tina. 2005. "Feminist Cultural Projects". Documenting Irish Feminisms: The Second Wave. Ed. Linda Connolly and Tina O'Toole. Dublin: Woodfield Press. 115-141.

Palacios González, Manuela. 2016. "Stand Still: Photographs of Irish Migrating Women”. ExSistere. Women's Mobility in Contemporary Irish, Galician and Welsh Literatures. Ed. María Jesús Lorenzo-Modia. Newcastle: Cambridge Scholars. 154-188.

Patten, Eve. 2006. "Contemporary Irish Fiction”. The Cambridge Companion to the Irish Novel. Ed. John Wilson Foster. Cambridge: Cambridge UP. 259-275.

Pelan, Rebecca. 2013. "Not the Same Sky. Book Review”. The Australasian Journey of Irish Studies, 13: 191-193.

Sharkey, Sabina. 1993. "Frontier Issues: Irish Women's Texts and Contexts". Women: A Cultural Review 4, 2: 125-135.

Terrazas Gallego, Melania. 2013. "The Rhetoric of Satire in Evelyn Conlon's 'Telling' (2000)". Revista Clepsydra, 12: 81-97.

Urry, John. 2007. Mobilities. Cambridge and Malden: Polity Press.

Walter, Bronwen. 2001. Outsiders Inside: Whiteness, Place and Irish Women. London and New York: Routledge.

Wills, Clair. 2002. "Contemporary Writing 1960-2001”. The Field Day Anthology of Irish Writing. Vol IV: Irish Women's Writing and Traditions. Ed. Angela Bourke et al. Cork: Cork UP. 1123-1129.

M. Teresa Caneda-Cabrera is a Senior Lecturer in English at the University of Vigo, Spain. She sits on the Editorial Board of European Joyce Studies and has published extensively on Joyce, modernism and translation. Her current research focuses on transnationalism, foreignness and mobility in relation to Contemporary Irish Fiction. 